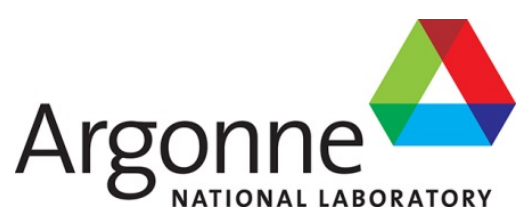

\title{
Analytical Results for Prepared UIUC F'LiNaK
}

Chemical Fuel Cycle Technologies Division 


\section{About Argonne National Laboratory}

Argonne is a U.S. Department of Energy laboratory managed by UChicago Argonne, LLC under contract DE-AC02-06CH11357. The Laboratory's main facility is outside Chicago, at 9700 South Cass Avenue, Argonne, Illinois 60439. For information about Argonne and its pioneering science and technology programs, see www.anl.gov.

\section{DOCUMENT AVAILABILITY}

Online Access: U.S. Department of Energy (DOE) reports produced after 1991 and a growing number of pre-1991 documents are available free at OSTI.GOV (http://www.osti.gov/), a service of the US Dept. of Energy's Office of Scientific and Technical Information.

Reports not in digital format may be purchased by the public from the National Technical Information Service (NTIS):

U.S. Department of Commerce

National Technical Information Service

5301 Shawnee Rd

Alexandria, VA 22312

www.ntis.gov

Phone: (800) 553-NTIS (6847) or (703) 605-6000

Fax: (703) 605-6900

Email: orders@ntis.gov

Reports not in digital format are available to DOE and DOE contractors from the Office of Scientific and Technical Information (OSTI):

U.S. Department of Energy

Office of Scientific and Technical Information

P.O. Box 62

Oak Ridge, TN 37831-0062

www.osti.gov

Phone: (865) 576-8401

Fax: (865) 576-5728

Email: reports@osti.gov

\section{Disclaimer}

This report was prepared as an account of work sponsored by an agency of the United States Government. Neither the United States Government nor any agency thereof, nor UChicago Argonne, LLC, nor any of their employees or officers, makes any warranty, express or implied, or assumes any legal liability or responsibility for the accuracy, completeness, or usefulness of any information, apparatus, product, or process disclosed, or represents that its use would not infringe privately owned rights. Reference herein to any specific commercial product, process, or service by trade name, trademark, manufacturer, or otherwise, does not necessarily constitute or imply its endorsement, recommendation, or favoring by the United States Government or any agency thereof. The views and opinions of document authors expressed herein do not necessarily state or reflect those of the United States Government or any agency thereof, Argonne National Laboratory, or UChicago Argonne, LLC. 


\section{Analytical Results for Prepared UIUC F7LiNaK}

prepared by

L.D. Gardner, M.A. Rose, and B. Cutrer

Chemical Fuel Cycle Technologies Division, Argonne National Laboratory

December 2021 


\section{Acknowledgements}

This research was performed using funding received from the DOE Office of Nuclear Energy's Nuclear Energy University Programs.

This work was conducted at Argonne National Laboratory and supported by the U.S. Department of Energy, Office of Nuclear Energy, under Contract DE-AC02-06CH11357. 


\section{INTRODUCTION}

Source materials including $275 \mathrm{~g}$ of ${ }^{7}$ LiF-NaF-KF (46.5-11.5-42.0 mol \%) and $10 \mathrm{~g}$ each of several reagent salts were prepared at Argonne for shipment to the University of Illinois at Urbana Champaign. The $\mathrm{F}^{7} \mathrm{LiNaK}$ was packaged in a single jar and reagent salts were placed in small vials. The mass of each shipped salt is listed in Table 1. This report contains details of the preparation procedure and results of elemental composition measurements using inductively coupled plasma-mass spectrometry (ICP-MS) and inductively coupled plasma-optical emission spectrometry (ICP-OES) and phase analyses using X-ray diffraction.

Table 1: Masses of $\mathrm{F}^{7} \mathrm{LiNaK}, \mathrm{LiF}, \mathrm{NaF}, \mathrm{KF}$, and $\mathrm{CeF}_{3}$ shipped

\begin{tabular}{cc}
\hline Salt & Mass (g) \\
\hline $\mathbf{F}^{7} \mathbf{L i N a K}$ & 275.7 \\
${ }^{7} \mathbf{L i F}$ & 10.02 \\
$\mathbf{N a F}$ & 10.03 \\
$\mathbf{K F}$ & 10.08 \\
$\mathbf{C e F}_{3}$ & 10.19 \\
\hline
\end{tabular}

\section{Reagent Preparation}

All activities related to salt preparation and packaging were performed in an argon atmosphere glovebox $\left(<5 \mathrm{ppm} \mathrm{O}_{2}\right.$ and $<1 \mathrm{ppm} \mathrm{H}_{2} \mathrm{O}$ ). The reagents were placed in graphite crucibles and heated at $300{ }^{\circ} \mathrm{C}$ for three hours and then at $700{ }^{\circ} \mathrm{C}$ for three hours to remove residual water prior to mixing. The ${ }^{7} \mathrm{LiF}$ and $\mathrm{NaF}$ were baked as single batches and the KF was baked in two batches (KF-1 and KF-2). The weight losses of the reagents were measured after six hours of total baking time and are listed in Table 2. Certificates of analysis for the reagents were obtained from the manufacturers and are attached in the appendix.

Table 2: Percent weight loss of reagents measured after drying

\begin{tabular}{cc}
\hline Salt & $\begin{array}{c}\text { Percent Loss by } \\
\text { Weight }\end{array}$ \\
\hline${ }^{7}$ LiF & $0.29 \%$ \\
NaF & $0.27 \%$ \\
KF-1 & $0.36 \%$ \\
KF-2 & $0.49 \%$ \\
\hline
\end{tabular}


A single batch of $\mathrm{F}^{7} \mathrm{LiNaK}$ was prepared by combining appropriate masses of the dried reagent salts to achieve a composition of 46.7-11.3-42.0 mol \% LiF-NaF-KF in a large graphite crucible. The target and batched masses of dried reagents are listed in Table 3 . The added amounts of each reagent were weighed using a balance accurate to $10 \mathrm{mg}$. The batch was mechanically mixed and then melted at approximately $700{ }^{\circ} \mathrm{C}$ for 6 hours. The crucible was left in the furnace to slowly cool. The salt ingot was then recovered from the inverted crucible in one solid piece. The ingot was broken up into chunks using a chisel and then crushed by using a stainless-steel mortar and pestle. The recovered salt was weighed and placed in a Mason jar, which was then sealed and stored in the glovebox. Weighed amounts of dried reagent powders and placed in plastic vials. All salt containers were vacuum sealed in plastic prior to shipping.

Table 3: Target and batched masses of reagents used in FLiNaK production

\begin{tabular}{ccccc}
\hline & ${ }^{7} \mathbf{L i F}$ & $\mathbf{N a F}$ & $\mathbf{K F}$ & Total \\
\hline Target Mass (g) & 84.714 & 33.913 & 171.373 & 289.99 \\
Batched Mass (g) & 84.70 & 33.92 & 170.90 & 289.52 \\
\hline Target Composition (mol \%) & 46.5 & 11.5 & 42.0 & 100 \\
Batched Composition (mol \%) & 46.55 & 11.52 & 41.93 & 100 \\
\hline
\end{tabular}

\section{Elemental Composition Analyses}

Approximately $5 \mathrm{~g}$ of the retained $\mathrm{F}^{7} \mathrm{LiNaK}$ was used in analyses performed at Argonne. The elemental composition of the mixture was measured by dissolving three samples $(179.5 \mathrm{mg}$, $184.9 \mathrm{mg}$, and $156.2 \mathrm{mg}$ ) in high-purity acid. The concentrations of the major cations were measured by using ICP-OES and the concentrations of impurities were measured by using ICPMS. The ICP-OES results and salt compositions are given in Table 4, where the fluoride contents were calculated by stoichiometry. Values measured using the ICP-OES technique are typically accurate to $\pm 5 \%$. The measured compositions are consistent across the three samples and with the as-batched and target compositions within the measurement uncertainty.

Table 4: Major Cation Analyses by ICP-OES and Calculated Salt Composition

\begin{tabular}{cccccccc}
\hline & \multicolumn{3}{c}{ Concentration, wt \% } & & \multicolumn{3}{c}{ Composition, mol \% } \\
\cline { 2 - 4 } \cline { 7 - 8 } & $\mathbf{L i}$ & $\mathbf{N a}$ & $\mathbf{K}$ & & LiF & NaF & KF \\
\hline Sample 1 & 7.27 & 6.18 & 38.7 & & 45.4 & 11.7 & 42.9 \\
Sample 2 & 7.38 & 6.19 & 37.6 & & 46.3 & 11.7 & 41.9 \\
Sample 3 & 7.46 & 6.27 & 37.8 & & 46.4 & 11.8 & 41.8 \\
\hline Average & 7.37 & 6.21 & 38.0 & & 46.1 & 11.7 & 42.2 \\
1 s & 0.01 & 0.05 & 0.6 & & 0.6 & 0.1 & 0.6 \\
\hline
\end{tabular}

Aliquots of the solutions used for ICP-OES analyses were further diluted and used to measure the amounts of trace contaminants in each $\mathrm{F}^{7} \mathrm{LiNaK}$ sample by using ICP-MS. These results are shown in Table 5. Values measured using the ICP-MS technique are typically accurate to $\pm 10 \%$. The concentrations of impurities measured in the salt were all less than $100 \mathrm{ppm}$, which is consistent with certified reagent purities. 
Table 5: Results of Trace Element Analyses by using ICP-MS (ppm)

\begin{tabular}{lccccccccc}
\hline & Be & Mg & Ca & Cr & Mn & Fe & Ni & Rb & Cs \\
\hline Sample 1 & $<0.05$ & $<0.33$ & 28 & 1.23 & 0.82 & $<14$ & 0.42 & 62 & $<0.02$ \\
Sample 2 & $<0.05$ & $<0.32$ & 25 & 0.41 & 0.66 & $<14$ & 0.23 & 55 & $<0.01$ \\
Sample 3 & $<0.06$ & $<0.38$ & 28 & 0.44 & 0.55 & $<16$ & 0.28 & 56 & $<0.01$ \\
\hline Average & BDL & BDL & 27 & 0.7 & 0.7 & BDL & 0.3 & 57 & BDL \\
1 s & - & - & 2 & 0.5 & 0.1 & - & 0.1 & 4 & - \\
\hline
\end{tabular}

$<$ indicates the concentration was below the reported detection limit.

\section{X-ray Diffraction Analyses}

Three portions of the salt ( $40 \mathrm{mg}, 140 \mathrm{mg}$ and $170 \mathrm{mg}$ ) were fixed to glass slides using doublesided tape and then covered with Kapton film for X-ray diffraction analysis. Figure 1 shows a comparison of the measured patterns to the combined pattern for LiF, NaF, and KF peaks. The locations of major peaks in the XRD patterns are generally consistent with the combined salt peaks. However, some discrepancies in peak locations are observed. Calibration was confirmed using a NIST silica reference material prior to sample measurements. The patterns were also compared with those of possible oxides and other contaminants (e.g., $\mathrm{Li}_{2} \mathrm{O}, \mathrm{Na}_{2} \mathrm{O}, \mathrm{K}_{2} \mathrm{O}, \mathrm{RbF}$, $\mathrm{Rb}_{2} \mathrm{O}, \mathrm{Fe}_{2} \mathrm{O}_{3}$ ) to verify that the salt samples were not contaminated with water during production, sample preparation, or analyses. No contaminant peaks were observed in the XRD pattern. This indicates contaminant concentrations are $<5 \mathrm{wt} \%$. This finding is consistent with the results of ICP-MS analyses.

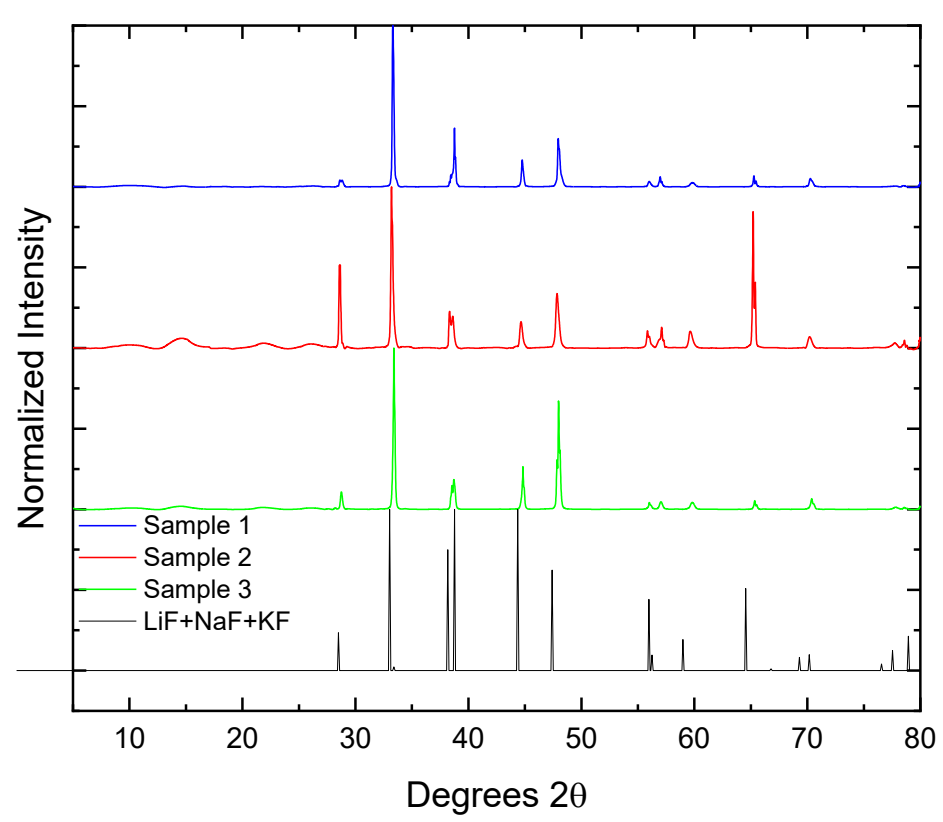

Figure 1: X-ray Diffraction Patterns for $\mathrm{F}^{7} \mathrm{LiNaK}$ Salt 


\section{Summary}

Materials including $275 \mathrm{~g}$ of ${ }^{7} \mathrm{LiF}-\mathrm{NaF}-\mathrm{KF}$ (46.5-11.5-42.0 mol \%) and $10 \mathrm{~g}$ each of several reagents were prepared at Argonne and shipped to UIUC to support experimental activities. Major cation compositions measured by using ICP-OES were consistent with the target eutectic composition and concentrations of trace elements measured by using ICP-MS were consistent with the certified purities of the reagents. 


\section{Appendix: Certificates of Analysis for Reagents}


Product Name:

\title{
Certificate of Analysis
}

Lithium-7 $\mathrm{Li}$ fluoride -99 atom \% ${ }^{7} \mathrm{Li}, 99 \%$ (CP)

$\begin{array}{ll}\text { Product Number: } & \mathbf{6 0 1 4 9 7} \\ \text { Batch Number: } & \text { MBBC0157V } \\ \text { Brand: } & \text { ALDRICH } \\ \text { CAS Number: } & 17409-87-9 \\ \text { Formula: } & \mathrm{F} 7 \mathrm{Li} \\ \text { Formula Weight: } & 26.01 \mathrm{~g} / \mathrm{mol} \\ \text { Quality Release Date: } & 19 \mathrm{SEP} 2016\end{array}$

\section{${ }^{7} \mathrm{LiF}$}

\begin{tabular}{lll} 
Test & Specification & Result \\
\hline Appearance (Color) & White & White \\
Appearance (Form) & Powder & Powder \\
Water (by Karl Fischer) & $\leq 0.5 \%$ & $0.2 \%$ \\
IC & $\geq 99.0 \%$ & $100.1 \%$ \\
Enrichment Li-7 & $\geq 99.00$ & 99.96 \\
\hline
\end{tabular}

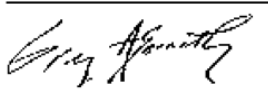

Greg Abernathy, QC Supervisor

Quality Assurance

Miamisburg, Ohio US

\begin{abstract}
Sigma-Aldrich warrants, that at the time of the quality release or subsequent retest date this product conformed to the information contained in this publication. The current Specification sheet may be available at Sigma-Aldrich.com. For further inquiries, please contact Technical Service. Purchaser must determine the suitability of the product for its particular use. See reverse side of invoice or packing slip for additional terms and conditions of sale.

Figure A.1: Certificate of Analysis for LiF Reagent 


\section{Sigma-Aldrich.}

3050 Spruce Street, Saint Louis, MO 63103, USA

Website: www.sigmaaldrich.com

Email USA: techserv@sial.com

Outside USA: eurtechserv@sial.com

\section{Product Name: \\ Certificate of Analysis}

Sodium fluoride - anhydrous, powder, 99.99\% trace metals basis

$\begin{array}{ll}\text { Product Number: } & 450022 \\ \text { Batch Number: } & \text { MKCN8615 } \\ \text { Brand: } & \text { ALDRICH } \\ \text { CAS Number: } & 7681-49-4 \\ \text { MDL Number: } & \text { MFCD00003524 } \\ \text { Formula: } & \mathrm{FNa} \\ \text { Formula Weight: } & 41.99 \mathrm{~g} / \mathrm{mol} \\ \text { Quality Release Date: } & 02 \mathrm{FEB} 2021\end{array}$

\begin{tabular}{|c|c|c|}
\hline Test & Specification & Result \\
\hline Appearance (Color) & White & White \\
\hline Appearance (Form) & Pow der & Pow der \\
\hline $\begin{array}{l}\text { Gravimetric Analysis } \\
\% \text { F With Lead Acetate }\end{array}$ & & $45.8 \%$ \\
\hline $\begin{array}{l}\text { ICP Major Analysis } \\
\text { Confirms Sodium Component }\end{array}$ & Confirmed & Conforms \\
\hline $\begin{array}{l}\text { Purity } \\
99.99 \% \text { Based On Trace Metals Analysis }\end{array}$ & Meets Requirements & Meets Requirements \\
\hline Trace Metal Analysis & $\leq 150.0 \mathrm{ppm}$ & $55.9 \mathrm{ppm}$ \\
\hline Boron (B) & & $4.0 \mathrm{ppm}$ \\
\hline Barium (Ba) & & $1.0 \mathrm{ppm}$ \\
\hline Calcium (Ca) & & $0.1 \mathrm{ppm}$ \\
\hline Chromium (Cr) & & $1.9 \mathrm{ppm}$ \\
\hline Cesium (Cs) & & $4.0 \mathrm{ppm}$ \\
\hline Iron (Fe) & & $18.3 \mathrm{ppm}$ \\
\hline Potassium (K) & & $16.4 \mathrm{ppm}$ \\
\hline Lithium (Li) & & $2.1 \mathrm{ppm}$ \\
\hline Magnesium $(\mathrm{Mg})$ & & $0.2 \mathrm{ppm}$ \\
\hline Manganese $(M n)$ & & $0.3 \mathrm{ppm}$ \\
\hline Nickel (Ni) & & $1.4 \mathrm{ppm}$ \\
\hline Strontium (Sr) & & $4.9 \mathrm{ppm}$ \\
\hline Titanium (Ti) & & $0.6 \mathrm{ppm}$ \\
\hline Zine $(Z n)$ & & $0.3 \mathrm{ppm}$ \\
\hline Zirconium ( $\mathrm{Zr}$ ) & & $0.3 \mathrm{ppm}$ \\
\hline
\end{tabular}

Sigma-Aldrich warrants, that at the time of the quality release or subsequent retest date this product conformed to the information contained in this publication. The current Specification sheet may be available at Sigma-Aldrich.com. For further inquiries, please contact Technical Service. Purchaser must determine the suitability of the product for its particular use. See reverse side of invoice or packing slip for additional terms and conditions of sale. 
3050 Spruce Street, Saint Louis, MO 63103, USA Website: www. sigmaaldrich.com Email USA: techserv@sial.com Outside USA: eurtechserv@sial.com

\section{Certificate of Analysis}

Product Number: $\quad 450022$

Batch Number: MKCN8615

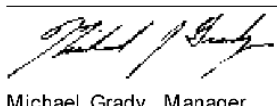

dy, Manager

Quality Control

Milwaukee, WI US

Sigma-Aldrich warrants, that at the time of the quality release or subsequent retest date this product conformed to the information contained in this publication. The current Specification sheet may be available at Sigma-Aldrich.com. For further inquiries, please contact Technical Service. Purchaser must determine the suitability of the product for its particular use. See reverse side of invoice or packing slip for additional terms and conditions of sale

Figure A.2: Certificate of Analysis for NaF Reagent 


\section{ThermoFisher \\ S C I E N T I F I C}

\section{Certificate of Analysis}

1 Reagent Lane

Fair Lawn, NJ 07410

201.796 .7100 tel

201.796.1329 fax

Thermo Fisher Scientific's Quality System has been found to conform to Quality Management System Standard ISO9001:2015 by SAI Global Certificate Number CERT - 0120632

This is to certify that units of the lot number below were tested and found to comply with the specifications of the grade listed. Certain data have been supplied by third parties. Thermo Fisher Scientific expressly disclaims all warranties, expressed or implied, including the implied warranties of merchantability and fitness for a particular purpose. Products are for research use or further manufacturing. Not for direct administration to humans or animals. It is the responsibility of the final formulator and end user to determine suitability based upon the intended use of the end product. Products are tested to meet the analytical requirements of the noted grade. The following information is the actual analytical results obtained.

\begin{tabular}{|c|c|c|c|}
\hline Catalog Number & 20135 & Quality Test / Release Date & $03 / 02 / 2020$ \\
\hline Lot Number & B0149551 & & \\
\hline Description & POTASSIUM FLUORIDE, ANHYDROUS & & \\
\hline
\end{tabular}

\begin{tabular}{|c|c|c|c|}
\hline \multicolumn{4}{|l|}{$N / A$} \\
\hline APPEARANCE & & REPORT & $\begin{array}{l}\text { WHITE POWDER, NOT } \\
\text { CRYSTALS }\end{array}$ \\
\hline ASSAY & $\%$ & $>=98.5$ & 99.68 \\
\hline CHLORIDE & $\mathrm{ppm}$ & $<=500$ & $<500$ \\
\hline SULFATE (SO4) & ppm & $<=500$ & $<500$ \\
\hline
\end{tabular}

Julian Burton

Julian Burton - Quality Control Manager - Fair Lawn

Note: The data listed is valid for all package sizes of this lot of this product, expressed as an extension of this catalog number listed above. If there are any questions with this certificate, please call at (800) 227-6701.

*Based on suggested storage condition.

Figure A.3: Certificate of Analysis for KF Reagent 


\section{ThermoFisher S C I E N T I F I C}

$\begin{array}{ll}\text { Product No:: } & 21118 \\ \text { Product: } & \text { Cerium(llI) fluoride, } 99.9 \% \text { (REO) } \\ \text { Lot No:: } & \text { S03G025 } \\ & \\ \text { CeF3 } & >99.9 \% \\ \text { Total remaining } & <0.1 \% \\ \text { RE-Oxides } & \\ \text { Retest date: June 3, } 2025\end{array}$

Find our products online therm ofisher.com/chemicals

This document has beenelectronically generated and does not require a signature.

Products are processed under IS 090012015 quality management systems and samples are tested for conformance to the noted specircations. Certain data may have been supplied bythird parties. Wie disclaim the implied warmanties of merchantability and fitness tor a particular purpose, and the accuracy ofthird party data or information associated with the product. Products are for research and development use only. Products are not br direct administration to humans or animals. $\mathbf{t}$ is the responsibility of the inal formulator or end user to determine suitability, and to qualify andior valid ate each product tor its intended use.

Figure A.4: Certificate of Analysis for $\mathrm{CeF}_{3}$ Reagent 


\section{Argonne}

Chemical Fuel Cycle Technologies Division

Argonne National Laboratory

9700 South Cass Avenue, Bldg. 205

Argonne, IL 60439

www.anl.gov

Argonne National Laboratory is a U.S. Department of Energy laboratory managed by UChicago Argonne, LL 